\title{
ASSESSMENT OF IMPACT OF CORPORATE INCOME TAX SUSPENSION ON FINANCIAL PERFORMANCE OF BUSINESSES
}

\author{
Valentīna BIZṆA ${ }^{1}$, Māris JURUŠS ${ }^{2}$, Tālis LAIZĀNS ${ }^{3}$, Roberts \\ ŠNIKVALDS ${ }^{4}$
}

1, 2, 3, ${ }^{4}$ Riga Technical University, Riga, Latvia

Corresponding author's e-mail: Maris.Juruss@rtu.lv

\begin{abstract}
Though there are a number of data and studies about the impact of tax incentives on investment, research and development, no detailed and systematic analysis has been elaborated on the effectiveness of taxation of profit to the financial performance of businesses in general. Businesses avoid corporate income tax to get more net profit. Evasion leads to economic stagnation. It is time to call for changes of the corporate income tax system and introduce tax suspension - tax only shared profit. The aim of the research is to assess the impact of corporate income tax suspension on retained corporate income. The research extends applicable theoretical foundation and comprehension of elements and factors affecting firms' behaviour. The results show that the corporate income tax reform would change capital structure of businesses and improve company's sustainability. The findings also give grounds for the development of an applicable model that would help government authorities choose the most effective way of taxation of corporate income.
\end{abstract}

Keywords: profit, corporate income tax, equity, financial performance, economic development.

JEL Classification: H25, C52, M21

\section{INTRODUCTION}

The degree of stability and reliability of tax legislation has the strongest influence on the sustainable functioning of country's businesses. Corporate income tax (CIT) is a crucial factor for entrepreneurial activity. Advance payments, tax on calculated profit or other regular tax charges reduce net profit, therefore, cash flow for future investment and development of businesses. Several studies have attempted to investigate the country-wide effect of changed rules for corporate income tax and potential results on financial performance of businesses if income tax is suspended (see, for example, the analysis by Guziejewska, Grabowski, \& Bryndziak, 2014), changes in company's capital structure and dividend distribution (for example, Hazak, 2009), and effects on performance (Masso, Meriküll, \& Vahter, 2013).

Businesses try to hide profit, increase business expenses or make other fictive activities to avoid deduction by the tax. 
Tax fraud impacts fair competition. Evasion leads to economic stagnation as banks do not loan businesses due to official bad financial performance results.

The aim of the research is to assess the impact of corporate income tax suspension on the retained corporate income. The tasks are to analyse the effects of the corporate tax reform in Estonia, to conclude and forecast the possible effects if the distributed profit taxation reform were introduced in Latvia.

There has been a huge gap between total investments in Estonia and Latvia. One of the reasons is the Estonian corporate tax system that gives them the competitive advantage over the neighbouring countries and diverts the investment flow to Estonia. Estonia uses the distributed taxation system that only taxes profit that is distributed compared to gross profit taxation system used in Latvia that taxes all profit (Eurostat, 2016).

According to the data on the accumulated foreign direct investments in the Baltic States (see Fig. 1), all Baltic States have an increase in investment since 2004.

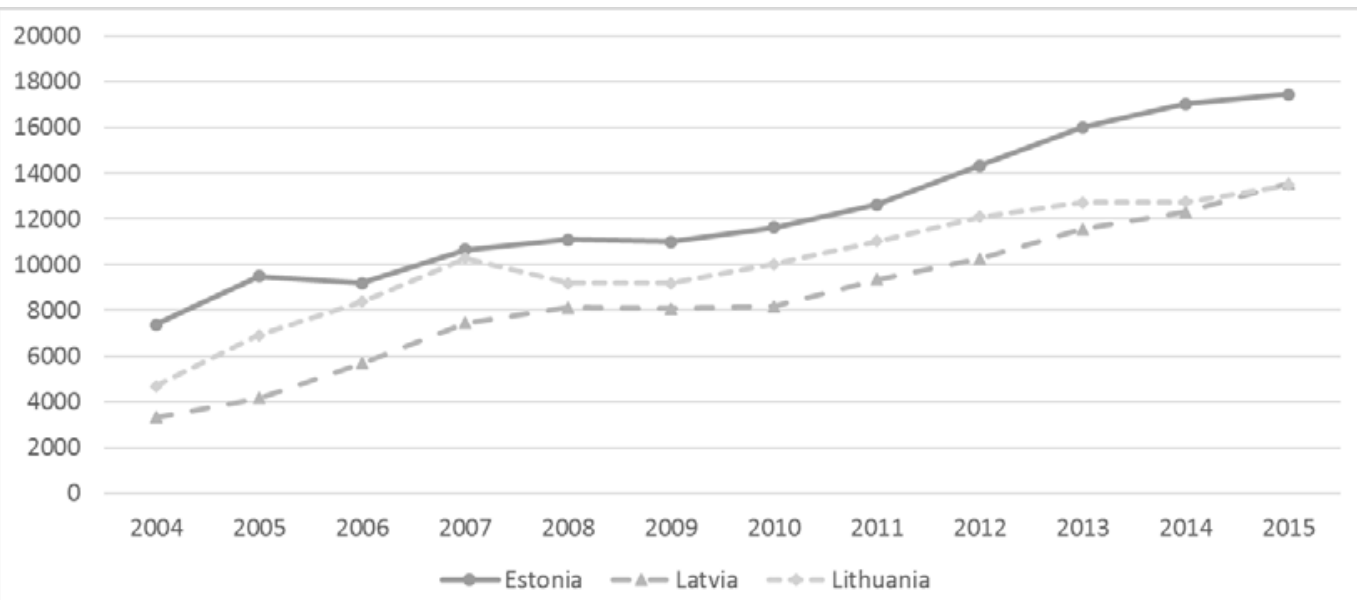

Fig. 1. Accumulated foreign direct investment in the Baltic States, million EUR (Ministry of Economics, 2016).

Figure 1 shows the accumulated foreign direct investment data in the Baltic States in period of 2004-2015. The amount of foreign investment in all three countries increased, and the fastest growth was in 2007 in all countries. In the period of 2008-2010, there was a decrease in foreign investment due to the economic crisis. Since 2010, the Baltic States have recovered upward indicators - an average of $7 \%-9 \%$ a year.

The highest foreign investment of the Baltic States is demonstrated by Estonia, where in 2004 foreign investment accounted to only 7374 million EUR and compared to 2015 it increased by 2.36 times, reaching 17462 million EUR.

Latvia has the lowest foreign investment in the Baltic States despite the fact that in 2015 the Latvian and Lithuanian data were at the same level, but it was observed that investment increased during the last 5 years, i.e., from 2010 to 2015 it increased by 5362 million EUR. Lithuania has similar investments as in Latvia, but from 2004 to 2015 investment increased by only 8807 million EUR. In 2015, the Latvian and Lithuanian data were similar - 13545 million EUR in Latvia and 13497 million EUR in Lithuania. Compared to Estonia, the amount of foreign 
investment in Latvia and Lithuania is less than in Estonia by approximately $22 \%$ $23 \%$.

The leader of foreign investment in Latvian business development is Sweden (18.2 \% of all foreign investments in 2016) and the main sector is finances and other services (Ministry of Economics, 2016).

Foreign direct investment is the main source for the development of businesses, their assets and labour productivity. Productivity data in the Baltic States have also grown from 2004 to 2015 (Ministry of Economics, 2016).

The Baltic States have similar productivity indicators - in the period of 20082009 it was the fastest negative growth of indicators, where a higher decline indicator compared to the previous year seemed to be in Lithuania. Since 2012, the Baltic States have experienced a moderate productivity growth - the lowest productivity growth is observed in Estonia, i.e., an average of 0.85 percentage points, while in the other Baltic States the data are similar - an average of 2 percentage points in Latvia and 1.5 percentage points in Lithuania. According to the data in 2016, the lowest productivity indicator was in Estonia - 106.0 and the highest indicator in Latvia - 115.4, Lithuania was similar to Latvia - 112.5.

Operation of businesses to attract investment affects all production and service processes, for which it is necessary to follow opportunities of improving the existing technical equipment, qualification of employees, and using the opportunity to acquire and introduce modern technologies that influence company's productivity.

\section{METHODS}

The present paper uses difference in differences (DiD) analysis method in order to assess the potential effects and results of the tax reform of 2018 in Latvia. The $\mathrm{DiD}$ analysis has been used as a control tool and measuring method to provide experts with sound results. A similar DiD approach was used to study the effect of corporate income tax reform in Estonia by Masso, Meriküll, and Vahter (2011, 2013).

The introduction of the tax reform should have minimal expectation result due to the fact that a new legislative package was approved by the Parliament of Latvia in December 2017 and enforced on 1 January 2018. Therefore, the law will affect all Latvian firms equally and concurrently. The pre-2018 tax system was a standard gross profit taxation system with a corporate tax rate of $15 \%$, while the post-2018 tax system reform will introduce identical redistributed profit taxation with a straight rate of $20 \%$ on profit which is not used to invest in the business development but paid-out as dividends.

\section{TAX SUSPENSION}

A possible solution might be corporate income tax suspensions which could motive business do not hide profit or fraud with expenses. Business will be motivated to increase profit as the state will no charge tax on it until shareholders do not share profit. The undistributed profit increase equity and therefore financial 
performance. It could be a call for banks to give loans to business activities; therefore, the process will stimulate economic development.

The hypothesis is that corporate income tax transformation from the existing system to the principle that tax is suspended until the distribution of profits has a positive effect, particularly on the financial performance of businesses (see Fig. 2).

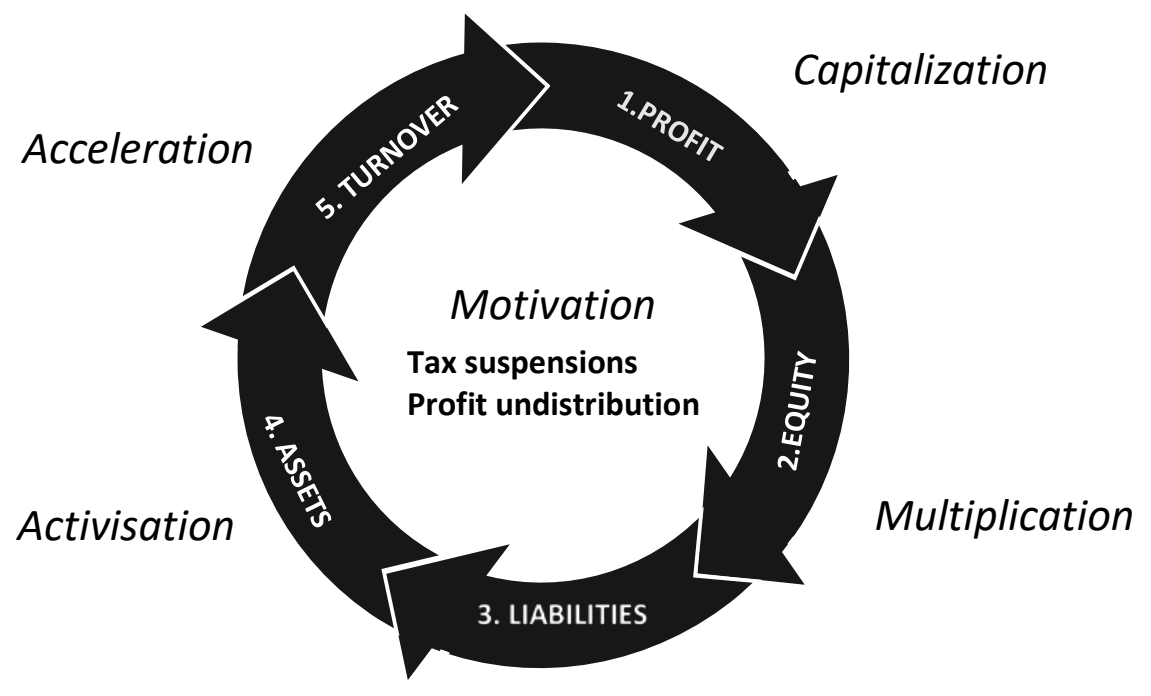

Fig. 2. Impact of tax suspensions on the financial performance of businesses (made by the authors).

Implementation of corporate income tax to distributed profit (see Fig. 2) has the five main effects on business financial performance. The main effect of tax suspension is business motivation in development.

Tax reform will affect the profit of businesses - there will be no tax on taxable income; therefore, businesses can use their undistributed profit for further business activities and development.

Undistributed profit will have positive growth in businesses equity (Capitalisation, Fig. 2). Equity consists of company's share capital, reserves and retained profit. Capital equity is one of the main data that investors are interested in because it shows the structure of capital and businesses' stability and independence from external resources.

Equity gives an opportunity to provide stable solvency due to a larger share of equity capital. Higher equity shows less dependence of borrowed capital - that is one of the attractiveness forces to investors. The growth of equity gives additional ways to get external funds to business development and, therefore, growth in assets.

Improvement of financial performance would have a more favourable effect on the development of business environment and increase of investments. The next effectiveness impact of tax suspension is activation - businesses will be motivated to develop their activity by additional investment in capital (Activation, Fig. 2).

Finally, the last positive impact of a new corporate tax reform will be acceleration, which means net sales increase (Acceleration, Fig. 2). 


\section{FINDINGS}

Applicable statistics and other relevant data have been analysed to find out correspondence for changed corporate tax regime via analysing quantitative (financial) results for different industries and comparing these theoretical projections with actual data and results from the Baltic States.

The data have been retrieved from Amadeus database. The relevant data about net profit, equity, assets and net turnover have been used.

According to statistical data about profit and loss in Latvia, there was not fast profit increase from 2010 to 2015 as we can see in Fig. 3.

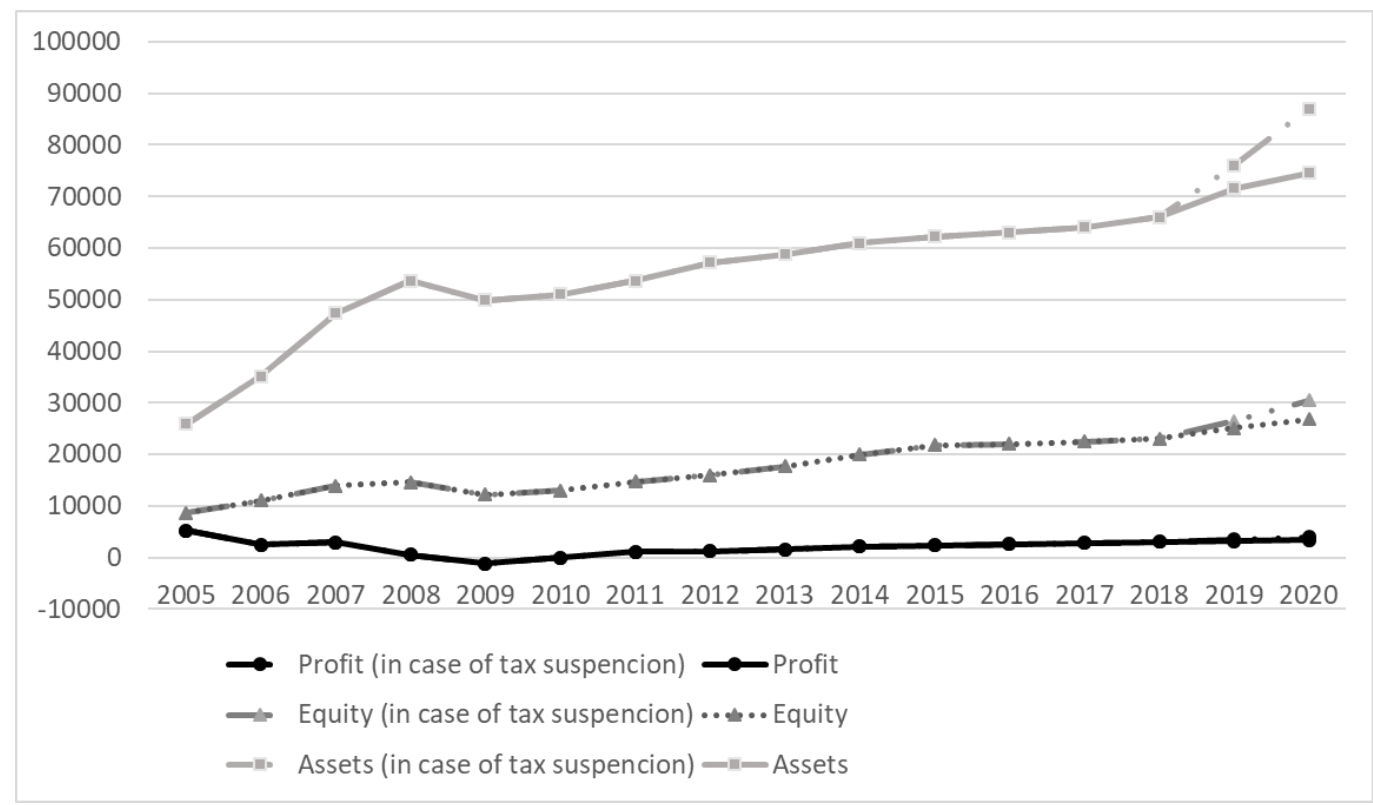

Fig. 3. Assessment of profit, equity, and assets of businesses in Latvia, million EUR (made by the authors using data from Amadeus, 2016).

Average profit increase during 2010-2015 was only $21.7 \%$. In 2009, businesses had negative profit that was caused by the economic crisis. Before there was positive profit, but it decreased compared to the amount in 2005. Profit data depend on business operational area or sector, operational specifics, and investments in assets affect profit, but the level of profit in 2005 still was not reached (see Fig. 3).

In 2015, Companies' equity in Latvia increased by 2.5 times compared to 2005. Even though in 2009 business data decreased to 16.9 percent compared to the previous year, since 2010 capital equity has had annual growth of $10.2 \%$. This means that increase in equity will provide opportunities to get additional investments. Analysing business structure in positive and negative equity showed that most of Latvian companies had positive capital equity, but a negative share of equity was still high. In 2015, the positive and negative equity ratio was 58 to 42, respectively, while in 2005 it was 71 to 29 . According to assessment by the authors, every year it will be the double growth of equity capital, potential $13 \%$ or 3.5 
billion EUR in Latvia (Fig. 3). According to the data about net sales, there has not been an increase in fast net sales since 2012 - an average of $3.6 \%$ each year. By 2015 there was an increase in assets that was similar to business equity. Positive assets growth shows that businesses are interested in development. The data in Fig. 3 outline that the amount of assets in Latvian businesses within the period of 10 years (from 2005 to 2015) increased reaching 62,240 million EUR in 2015. The decrease of assets observed in 2009 as in equity shows a connection with both indicators.

After introducing tax suspension in Latvia, there could be a potential investment increase by 10 billion EUR that could be used as a resource to invest in their fixed and current assets. Assets are related to liquidity ratio that implies business ability to cover short-term liabilities with existing funds and sources. Business activity after tax reform would affect their net turnover - potential growth of $12 \%$ or 10 billion EUR (see Fig. 3).

Therefore, tax suspension will have a positive impact on financial position, stability, productivity and export opportunities for businesses in Latvia.

\section{DISCUSSION}

Investors' decision to invest in any of the countries may be dependent on several factors. CIT rate is one of the following factors (Guziejewska, Grabowski \& Bryndziak, 2014). There can be several options for taxation of profit, including integrated approach, according to which the individual income taxes can provide to shareholders a credit for corporate taxes paid on distributed dividends (Graetz \& Warren, 2016). To avoid double taxation of company income and dividends distributed to shareholder, only one type of tax might be applied (Nasyrov \& Shtyrlyaeva, 2015).

Changes in tax system may lead to competitive advantage growth among other countries as the development of fixed assets, technologies, investments. That also gives to companies export growth opportunities (Jurušs, Stinka \& Kūma, 2017).

The research of corporate income tax on distributed profit in Estonia showed that liquidity of businesses increased by an average of $2 \%$ after tax reform implementation compared to Latvia and Lithuania, this indicator was larger by 2 times for small firms (Masso, Meriküll \& Vahter, 2013).

The research already carried out shows that Latvian net turnover in 2014 was lower by $10.7 \%$ than in Estonia. Net sales growth after tax suspension per capita in Estonia increased by 3.9 times that confirmed positive effect not only on businesses performance but also on productivity (Prohorovs, Fainglozs \& Jonina, 2016).

In Latvia and Lithuania there used to be a classical or traditional corporate tax income system, which is different from the Estonian corporate income tax system. In Estonia, the corporate tax system on distributed profit was implemented in 2000, which provided tax payment only at the time when profit was distributed. The main feature of such a system is the distribution of profit according to the businesses' decision, hence, the planning of tax payments. Classical corporate tax income system differs from distributed profit taxation as the tax calculation applies to the 
taxation period of business profit (Hazak, 2009). Estonian corporate income tax rate on distributed profit is $20 \%$ while Latvia (by 2017) and Lithuania have $15 \%$ tax rate on taxable base. In the case of classical CIT systems, there is double taxation corporate income tax and also personal income tax for dividends interact in common (Gruevski \& Gaber, 2015).

One of the reasons to tax suspension can be tax impact on investments, for example, impact on the liquidity of businesses that lead to mutual caution between investors and companies, which reduces opportunities to obtain additional funds. The corporate tax system at the international level is also affected by tax calculations, reliefs and exemptions specific of each country. It creates an incentive for companies to look for a better place for investments and profit distribution (Gorter \& Mooij, 2001).

There are many types of research into the effectiveness of corporate income taxation. The studies regarding the effects of corporate income tax reform in Estonia concluded the positive impact on economic development (Hazak, 2007; 2009).

There was also observed a positive effect on investment and labour productivity (Masso, Meriküll \& Vahter, 2011).

It posed a more valuable effect on investment amount growth for small firms an increase of only $0.37 \%$, and an increase in the investment rate by 0.203 percentage points. The share of investments in the capital of businesses increased by $20 \%$. Analysing the impact of tax reforms on labour productivity, there was such an assumption that fast-growing companies could increase the employment rate to affect common indicators. The observation showed that productivity indicators increased by 0.134 percentage points over four years since the implementation of tax reforms in Estonia compared to Latvia and Lithuania (Masso, Meriküll \& Vahter, 2011).

The impact of tax reforms on businesses liabilities in total assets was also researched - there was a decrease in an average of $5.7 \%$. Business liquidity after the corporate tax reform in Estonia had 2 \% growth and undistributed profit share in total assets grew by $8.1 \%$ compared to Latvia and Lithuania - these research results showed that a bigger effect exerted on small businesses (Masso, Meriküll \& Vahter, 2013). This confirms that small businesses are more affected by tax changes and reforms that require them to look for additional funds in order to adapt to these changes.

The reform did not change the structure of their investments but rather helped increase their size so that they could buy better and more expensive machinery, for example (Masso, Meriküll \& Vahter, 2011, 2013).

Tax reform implementation in Estonia gave an enormous difference between businesses capital equity in Estonia and Latvia - Estonian capital equity of businesses increased by 3.5 times in the period from 2004 to 2014. After tax reform implementation in Latvia, there was a positive impact $-2.44 \%$ of gross domestic product growth in next 10 years. The reform has increased the entrepreneurial activity and has been one of the driving forces for the growth in the Estonian economy (Prohorovs, Fainglozs \& Jonina, 2016). 
Corporate tax reform in Estonia increased the total tax revenues collected, at the same time reducing administrative burden and costs of tax administration. (Jurušs, Stinka \& Kūma, 2017).

Such a tax reform made easier administration in Estonia and also motivated companies to not avoid tax payments. Compared to the Latvian corporate tax calculation, the adjustments on taxable income contribute to errors and therefore make the tax calculation and administration more complicated.

Tax suspension in Latvia can be the main force to business development as they can use additional funds to increase their assets and investment attractiveness opportunities. This can also solve the double taxation problem of corporate income tax and personal income tax - there will be one tax instead of two (Jurušs, Stinka \& Kūma, 2017).

Latvian companies have higher tax burden on labour. The corporate income tax system in Latvia is the least competitive. Lithuania provides favourable conditions for entrepreneurs by offering a lower effective CIT rate corresponding to the tax actually paid (Domnīca Certus, 2016).

\section{CONCLUSION}

The distributed profit taxation system can be one of the main forces for the country's economy to grow. It increases the entrepreneurial activity and encourages foreign and local investment in the country. The increase in the investment allows companies to improve their quality of investment and productivity, which allows them to rapidly increase their revenues and profit in the future.

In the conditions of the distributed profit taxation system, the number of liabilities in total assets decreases and liquid assets like cash in total assets increase making the company's capital structure stronger and increasing their sustainability.

The reform also decreases the need of companies to hide or manipulate their profit to decrease taxes payable. Due to this reason, the total amount of unaccounted part of the economy will decrease increasing the total tax revenue and making companies more transparent.

\section{REFERENCES}

Amadeus. (2016). A Database Containing Financial Information on Approximately 8 Million Public and Private Companies in 38 European Countries. Retrieved from https://www.bvdinfo.com/en-us/ourproducts/company-information/international-products/amadeus

Badertscher, B., Katz, S. P., \& Rego, S. O. (2009). The Impact of Private Equity Ownership on Corporate Tax Avoidance. Harvard Business School Working Papers 10-004. Retrieved from: https://ideas.repec.org/p/hbs/wpaper/10-004.html

Devereux, M. P., Griffith, R., \& Klemm, A. (2002). Corporate Income Tax Reforms and International Tax Competition. Economic policy, 17(35), 449-495. https://doi.org/10.1111/1468-0327.00094

Domnīca Certus. (2016). Competitiveness of Latvia. Report about Taxation. Retrieved from http://certusdomnica.lv/

Eurostat. (2016). Foreign Direct Investments in \% of GDP. Retrieved from: http://ec.europa.eu/eurostar

Gorter, J., \& Mooij, R. A. (2001). Capital Income Taxation in Europe: Trends and Trend-offs. Retrieved from:https://www.researchgate.net/profile/Ruud_Mooij/publication/4748914_Capital_Income_Taxation_i n_Europe_Trends_and_Trade-offs/links/00b4952323a5b54055000000.pdf

Graetz, M. J., \& Warren Jr., A. C. (2016). Integration of Corporate and Shareholder Taxes. National Tax Journal, 69(3), 677-700. https://doi.org/10.17310/ntj.2016.3.07 
Gruevski, I., \& Gaber, S. (2015). Classical Corporation Tax System: the Classical Model of Pure "Double" Taxation of Company's Income. Economic Development, 17(3), 241-254.

Guziejewska, B., Grabowski, W., \& Bryndziak, S. (2014). Tax Competition Strategies in Corporate Income Tax - the Case of EU Countries. Business \& Economic Horizons, 10(4), 253-271. https://doi.org/10.15208/beh.2014.21

Hazak, A. (2007). Companies’ Financial Decisions under the Distributed Profit Taxation Regime of Estonia. Working Papers in Economics, TUTWPE No 155, 5-19. Retrieved from: http://deepthought.ttu.ee/majandus/tekstid/TUTWPE_07_155.pdf

Hazak, A. (2009). Companies' Financial Decision under the Distributed Profit Taxation Regime of Estonia. Emerging Markets Finance \& Trade, 45(4), 4-12. https://doi.org/10.2753/REE1540-496X450401 .

Jurušs, M., Stinka, J., \& Kūma, E. (2017, May). Shifting from Taxation of Corporate Income to Distributed Profit: The Concept for Latvia. XVIII Turiba University Conference Communication in the Global Village: Interests and Influence. 88-95.pp. Retrieved http://www.turiba.lv/f/Conference_XVIII_Turiba_18.05.2017.FINAL.pdf

Masso, J., Meriküll, J., Vahter, P. (2011). Gross Profit Taxation Versus Distributed Profit Taxation and Firm Performance: Effects of Estonia's Corporate Income Tax Reform. University of Tartu: Faculty of Economics and Business Administration Working Paper Series, No. 81, 1-33. https://doi.org/10.2139/ssrn.1793143

Masso, J., Meriküll, J., \& Vahter, P. (2013). Shift from Gross Profit Taxation to Distributed Profit Taxation: Are There Effects on Firms? Journal of Comparative Economics, 41, 1092-1105. https://doi.org/10.1016/j.jce.2013.01.011

Ministry of Economics (2016). Report on the Latvian economy. Retrieved November 7, 2016, from https://www.em.gov.lv/files/tautsaimniecibas_attistiba/2016_jun.pdf.

Nasyrov, N., \& Shtyrlyaeva, V. (2015). The Need to Cancel the Double Taxation of Dividends. Finance \& Credit, 21(17), 46-52.

Prohorovs, A., Fainglozs, L., \& Jonina, V. (2016). Introduction of the Deferral of corporate Income Tax before the Distribution of Company Profits as an Essential Factor for the Development of the Latvian Economy. RISEBA Working Paper 16/9. https://doi.org/10.2139/ssrn.2939173

\section{AUTHORS' SHORT BIOGRAPHIES}

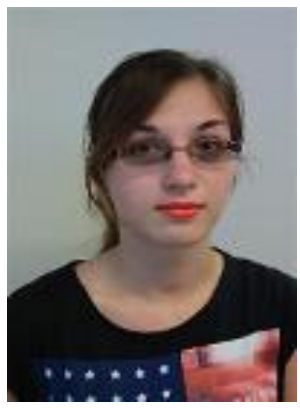

Valentīna Bizṇa holds a Bachelor’s Degree.

Valentīna Biznna is a student at the Faculty of Engineering Economics of Riga Technical University. She has been involved in several types of research at RTU about corporate income taxation in Latvia.

E-mail: valentina.bizna@inbox.lv

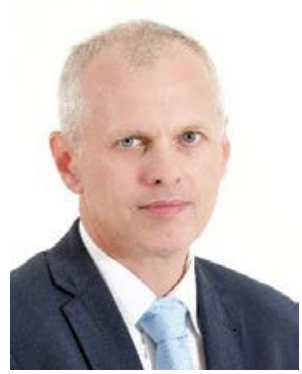

Māris Jurušs, Dr.oec., Assistant Professor.

Māris Jurušs obtained Dr. oec. degree from the Faculty of Engineering Economics at Riga Technical University in 1999. He made research project “Theoretical Aspects of Improvement of Tax System”. He worked for the Ministry of Finance from 1996 to 2007. He was involved in many European Commission and Council's working groups during Latvian tax legislation harmonisation with the EU principles. From 2007 to 2012, he worked for PricewaterhouseCoopers as a Tax Manager. He was involved in many tax projects regarding excise duty, customs matter and others. Since 2012, Māris Jurušs is Assistant Professor at Riga Technical University. He has been involved in many study programs and courses.

E-mail: Maris.Juruss@rtu.lv 


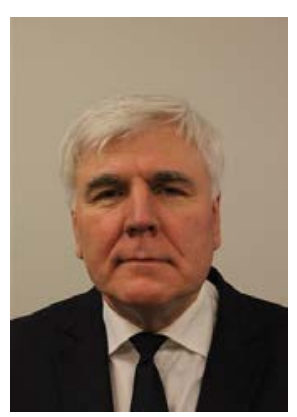

Tālis Laizāns holds a Master’s Degree in Economics.

Tālis Laizāns is an Associated Professor, Researcher at Riga Technical University. He is a Lecturer at MBA Programme "Innovation and Entrepreneurship" and Master Study Programme "Finances of Entrepreneurship". He delivers the study courses "Corporate Finance", "Entrepreneurship and Planning”, "Financial Risks”, "Financial Innovation”, "Financial Markets and Investments".

List of publications is related to management, venture capital, corporate finance.

E-mail: Talis.Laizans@rtu.lv

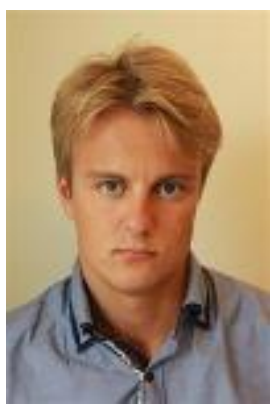

Roberts Šnikvalds holds a Bachelor's Degree in Economics.

Roberts Šnikvalds is a student at Riga Technical University. Field of study: logistics, materials and supply chain management.

E-mail: roberts.snikvalds@outlook.com 